\title{
SISTEM PENDUKUNG KEPUTUSAN PENGUKUR KINERJA KARYAWAN PADA RUMAH MAKAN WONG SOLO KEDIRI MENGGUNAKAN METODE TOPSIS
}

\author{
Elitta Saharlan*1, Muhaji Bayu Suryawan² \\ ${ }^{1}$ Sekolah Tinggi Teknologi Cahaya Surya Kediri \\ ${ }^{2}$ Sekolah Tinggi Teknologi Cahaya Surya Kediri \\ Email: ${ }^{1}$ elitta.saharlan@gmail.com, ${ }^{2}$ bayu.ms@gmail.com
}

\begin{abstract}
ABSTRAK
Saat ini rumah makan Wong Solo masih menggunakan cara manual untuk mengetahui kelompok karyawan yang berprestasi dan kurang kompeten, maka dari itu dibuatlah sebuah penelitian yang berjudul "Sistem Pendukung Keputusan Pengukur Kenierja Karyawan pada Rumah Makan Wong Solo Kediri Menggunakan Metode TOPSIS (Technique For Other Reference by Similarity Ideal Solution), Tujuan penelitian ini adalah mampu mengimplementasikan metode TOPSIS dalam sistem pendukung keputusan untuk mengukur kinerja karyawan dan mampu membangun sistem pendukung keputusan yang membantu mengukur kinerja Karyawan Wong Solo.

Metode penelitian ini menggunakan beberapa tahapan yaitu: menyusun perencanaan, melaksanakan tindakan, melaksanakan pengamatan, melakukan refleksi. Adapun sumber data diperoleh dari observasi, wawancara, dan study Literature. Kemudian Landasan teori yang akan digunakan dalam sistem pendukung keputusan penilai kinerja karyawan rumah makan Wong Solo dengan Metode TOPSIS.

Berdasarkan analisa data yang dilakukan, diperoleh kesimpulan bahwa Metode TOPSIS dapat diterapkan ke dalam sistem pendukung keputusan pengukur kinerja karyawan yang digunakan sebagai rekomendasi HRD rumah makan Wong Solo Kediri untuk menentukan karyawan terbaik dan terburuk. Perhitungan menggunakan Metode ini sesuai dengan perhitugan manual. Diharapkan dengan adanya sistem ini, pihak Rumah Makan Wong Solo khususnya HRD dapat mengukur kinerja karyawan dengan lebih efisien dan cepat dari pada dengan cara manual.
\end{abstract}

Kata kunci: Sistem Pendukung Keputusan, Metode TOPSIS, Kinerja Karyawan. 


\begin{abstract}
Currently Wong Solo restaurant still uses a manual method to find out which groups of employees are outstanding and not competent, therefore a study was made entitled "Decision Support Systems for Employee Performance Measurement at Kediri Wong Solo Restaurant Using the TOPSIS Method (Technique For Other Reference by Similarity Ideal Solution ", which has the formulation of the problem of how to design a decision support system using the Reference Technique for Others method by Similarity to Ideal Solution, and how to implement a decision support system for employee performance measurement in Wong Solo restaurant. Decision support system is used to measure employee performance and be able to build a decision support system that helps measure the performance of Wong Solo employees.

The research method uses several stages: planning, implementing actions, carrying out observations, reflecting. The data sources are obtained from observations, interviews, and literature studies. Then the theoretical basis that will be used in the decision support system of the employee performance appraisers of Wong Solo restaurant with the TOPSIS Method (Technique For Other Reference by Similarity Ideal Solution).

Based on the data analysis carried out, it was concluded that the TOPSIS method can be applied to the decision support system of employee performance measurement used as a HRD recommendation for the Wong Solo Kediri restaurant to determine the best and worst employees. Calculation using this method is in accordance with manual attention. It is expected that with this system, Wong Solo Restaurant especially HRD can measure the employee performance more efficiently and quickly than by manual method.
\end{abstract}

Keywords: Decision Support System, TOPSIS Method, Employee Performance. 


\section{PENDAHULUAN}

Rumah Makan Wong Solo membutuhkan sistem pendukung keputusan untuk mengetahui kelompok karyawan yang kurang kompeten dan kelompok karyawan yang berkwalitas. Selama ini Rumah Makan Wong Solo dalam proses penentuan masih menggunakan cara manual, yaitu di catat di buku dan melakukan penilaian secara subyektif saja oleh HRD bersama manager. Dengan cara konvensional pihak HRD (Human Resources Departement) kesulitan dan membutuhkan waktu yang lama, serta kurang efektif serta hasil penanganannya kurang valid. Kriteria dalam menentukan penilaian kinerja karyawan meliputi kedisiplinan, absensi, ketelitian dan quality control. Kriteria ini akan memberi bobot penilaian setiap karyawan yang nantinya akan di hitung dengan metode TOPSIS sehingga menghasilkan data penilaian kinerja karyawan. Ketika outlet Rumah Makan Wong Solo dalam keadaan sepi order, maka akan ada pengurangan karyawan. Dan setiap bulan akan ada pemberian bonus kepada karyawan berprestasi, oleh sebab itu HRD selalu kesulitan untuk menentukan keputusan. Dengan sistem penentuan keputusan ini diharapkan HRD akan terbantu dalam menentukan siapa yang akan di PHK (Pemutusan Hubungan Kerja) dan siapa yang akan di berikan bonus dengan cepat dan akurat.

Ada beberapa penelitian sebelumnya yang menjadi acuan penulis. Pertama, penelitian yang dilakukan oleh Moh Ramdhan Arif Kaluku dan Ferry Jie dengan judul “ Penerapan ANP-TOPSIS untuk Pengukur Kinerja Human Resources Procedurement Section", penelitian ini dapat mengidentifikasi pegawai berdasarkan KPI, KPI berpengaruh terhadap kinerja Human Resource sebagai penilaian bobot. Hasil analisa pada studi Procurement Section memiliki nilai yang berbeda.

Kedua, penelitian yang dilakukan oleh Helmi Kurniawan (2015) dengan judul “ Sistem Pendukung Keputusan Penilaian Kinerja Karyawan Menggunakan Metode TOPSIS Berbasis Web Pada CV. Surya Network Indonesia”, penelitian ini berhasil menunjukkan kinerja karyawan, untuk mempermudah manager dalam mengawasi apabila karyawan kurang baik dalam berkerja, dan memotivasi agar lebih giat bekerja.

Ketiga, penelitian oleh Reflin Yadi, Muhammad Sobri dan Suzi Oktavia Kunang yang berjudul “ Implementasi Metode TOPSIS untuk Menentukan Karyawan Terbaik di PT. KFC Cabang Demang”. Penelitian ini mempermudah admin dalam memasukkan data-data karyawan dan manager untuk menginputkan nilai pembobotan, maka hasilnya 
akan diketahui secara otomatis dan bisa langsung dilihat peringkat dari setiap penilaian karyawan.

Tujuan yang ingin dicapai dalam pembuatan program aplikasi penelitian ini adalah mampu mengimplementasikan metode Technique for Others reference by Similarity to Ideal Solution dalam sistem pendukung keputusan untuk mengukur kinerja karyawan dan mampu membangun sistem pendukung keputusan yang membantu mengukur kinerja Karyawan Wong Solo.

\section{METODE PENELITIAN}

Methoda penelitian ini dilakukan secara kwantitatip melalui analisa dengan data primer dan sekunder, kemudian data dikumpulkan dengan cara observasi, wawancara dan studi perpustakaan, kemudian dengan pendekatan subjective, objektif dan pendekatan integrasi antara subjektif dan objektif maka digunakan fuzzy multiple attribute decision untuk menentukan bobot setiap attribute dan perengkingan, sedangkan pengambilan keputusan digunakan methoda TOPSIS

\subsection{Analisis Data}

\section{a. Jenis Data Penelitian}

Data yang di kumpulkan untuk melakukan penelitian ini terbagi menjadi 2 kelompok yaitu:

1. Data Primer

Data primer adalah data yang didapatkan dengan cara observasi langsung ke lokasi penelitian. Dan juga didapatkan dengan cara wawancara kepada sumber - sumber yang kompeten di Rumah Makan Wong Solo.

2. Data Sekunder

Data Sekunder adalah data yang didapat dengan cara mengutip data yang telah dikumpulkan oleh pihak lain sebelumnya. Dengan cara studi literatur dan studi dokumentasi.

\section{b. Metode Pengumpulan Data}

Pengumpulan data dapat dilakukan dengan cara:

1. Observasi

Yaitu melakukan pengamatan langsung di Rumah Makan Wong Solo Kediri

2. Wawancara

Yaitu melakukan tanya jawab kepada HRD dan Manager Rumah Makan Wong Solo Kediri 


\section{Literature}

Yaitu membaca data-data baik berupa buku pedoman ataupun arsip yang ada di lokasi penelitian.

\section{c. Fuzzy Multiple Attribute Decision Making (FMADM).}

FMADM adalah suatu metode yang digunakan untuk mencari alternatif optimal dari sejumlah alternatif dengan kriteria tertentu. Inti dari FMADM ialah penentuan bobot untuk setiap atribut yang kemudian dilakukan proses perangkingan. Pada dasarnya ada tiga pendekatan untuk mencari nilai bobot atribut, yaitu pendekatan subyektif, pendekatan objektif dan pendekatan integrasi antara subjektif dan objektif.

\section{d. TOPSIS (Metode Technique For Other Reference by Similarity Ideal Solution)}

Metode TOPSIS adalah salah satu metode pengambilan keputusan multikriteria yang pertama kali diperkenalkan oleh Yoon dan Hwang pada tahun 1981. Metode ini merupakan salah satu metode yang digunakan untuk pengambilan keputusan secara praktis. TOPSIS memiliki konsep dimana alternatif yang terpilih merupakan alternatif terbaik yang memiliki jarak terpendek dari solusi ideal positif dan jarak terjauh dari solusi ideal negatif.

\section{Langkah-lahkah metode TOPSIS sebagai berikut :}

a. Menentukan matriks keputusan yang ternormalisasi (R), seperti persamaan 1 .

$$
r_{i j}=\frac{x_{i j}}{\sqrt{\sum_{i=1}^{m} x_{i j}^{2}}},(\mathrm{i}=1,2, \ldots, \mathrm{n} ; \mathrm{j}=1,2, \ldots, \mathrm{m})
$$

keterangan:

$\mathrm{x}_{\mathrm{ij}}$ merupakan rating kinerja alternatif ke- ${ }_{-\mathrm{i}}$ terhadap atribut ke- $\mathrm{j}$ $\mathrm{r}_{\mathrm{ij}}$ adalah elemen dari matriks keputusan yang ternormalisasi.

b. Menentukan matriks keputusan yang terbobot (Y), seperti persamaan 2 .

keterangan:

$$
\mathrm{y}=\left[\begin{array}{cccc}
y_{11} & y_{12} & \ldots & x_{i j} \\
y_{21} & y_{22} & \ldots & x_{2 j} \\
y_{i 1} & y_{i 2} & \ldots & x_{i j}
\end{array}\right] \text { untuk } \mathrm{y}_{\mathrm{ij}}=\mathrm{w}_{\mathrm{j}} \mathrm{r}_{\mathrm{ij}}
$$

$\mathrm{w}_{\mathrm{j}}$ adalah bobot dari kriteria ke- $\mathrm{j}$

$\mathrm{y}_{\mathrm{ij}}$ adalah elemen dari matriks keputusan yang ternormalisasi terbobot

c. Menentukan matriks solusi ideal positif $(\mathrm{A}+)$ dan matriks solusi ideal negatif (A-), seperti persamaan 3 dan persamaan 4 .

$$
\begin{aligned}
A^{+} & =\left(\mathrm{y}_{1}^{+}, \mathrm{y}_{2}^{+}, \ldots ., \mathrm{y}_{\mathrm{j}}^{+}\right) \\
\mathrm{A}^{-} & =\left(\mathrm{y}_{1}^{-}, \mathrm{y}_{2}^{-}, \ldots . ., \mathrm{y}_{\mathrm{j}}^{-}\right)
\end{aligned}
$$


Dengan

$$
\begin{aligned}
& y_{j}{ }^{+}=\left\{\begin{array}{c}
\max _{i} y_{i j} \\
\min _{i}
\end{array} y_{i j}\right. \\
& y_{j}{ }^{-}=\left\{\begin{array}{c}
\max y_{i j}, \\
\min _{i} y_{i j}
\end{array}\right.
\end{aligned}
$$

d. Menentukan jarak nilai alternatif dari matriks solusi ideal positif $\left(\right.$ di $\left.^{+}\right)$dan matriks solusi ideal negatif (di), jarak solusi ideal positif $\left(\mathrm{di}^{+}\right)$seperti persamaan 5.

$d_{i^{+}} \sqrt{\sum_{j=1}^{m}\left(y_{i j}-y_{j^{+}}\right)^{2}}$, dengan $i=1,2,3, \ldots, m$

keterangan:

$\mathrm{y}_{\mathrm{j}}^{+}$adalah elemen dari matriks solusi ideal positif jarak solusi ideal negatif

(di ) seperti persamaan 6

$$
d_{i^{-}} \sqrt{\sum_{j=1}^{m}\left(y_{i j}-y_{j^{-}}\right)^{2}}, \text { dengan } i=1,2,3, \ldots, m
$$

keterangan:

$\mathrm{y}_{\mathrm{j}}^{-}{ }^{-}$adalah elemen dari matriks solusi ideal negatif

e. Menentukan nilai preferensi (ci) untuk setiap alternatif. Nilai preferensi merupakan kedekatan suatu alternatif terhadap solusi ideal, seperti persamaan 7.

$$
C_{i}=\frac{d_{i^{-}}}{d_{i^{*}}+d_{i^{+}}}
$$

keterangan:

nilai $\mathrm{c}_{\mathrm{i}}$ yang lebih besar menunjukkan prioritas alternatif.

\subsection{Perancangan Sistem}

\section{Flowchart}

Flowchart atau diagram alur adalah gambaran simbol - simbol yang digunakan untuk menggambarkan urutan proses atau instruksi-instruksi yang terjadi didalam suatu program komputer secara sistematis dan logis (Sugiono, 2009). Berikut simbol yang digunakan dalam pembuatan flowchart. 


\section{Tabel 2.1 Simbol Flowchart}

\begin{tabular}{|c|c|}
\hline Simbol & Keterangan \\
\hline & $\begin{array}{l}\text { Sebagai simbol START atau END untuk memulai } \\
\text { ataupun mengakhiri flowchart. }\end{array}$ \\
\hline & $\begin{array}{l}\text { Input atau output } \\
\text { Digunakan untuk menuliskan proses menerima data } \\
\text { atau mengeluarkan data. }\end{array}$ \\
\hline & $\begin{array}{l}\text { Proses } \\
\text { Digunakan untuk menuliskan proses }\end{array}$ \\
\hline & $\begin{array}{l}\text { Conditional/Decision } \\
\text { Digunakan untuk menyatakan proses yang } \\
\text { membutuhkan keputusan. }\end{array}$ \\
\hline & $\begin{array}{l}\text { Prepatation } \\
\text { Digunakan untuk memberikan nilai awal }\end{array}$ \\
\hline & $\begin{array}{l}\text { Arrow } \\
\text { Sebagai penunjuk arah dan alur proses }\end{array}$ \\
\hline & $\begin{array}{l}\text { Connector (on-page) } \\
\text { Digunakan untuk menyatukan beberapa arrow }\end{array}$ \\
\hline & $\begin{array}{l}\text { Connector (off-page) } \\
\text { Digunkan untuk menghubungkan flowchart yang } \\
\text { harus digambarkan pada halaman yang berbeda. }\end{array}$ \\
\hline & $\begin{array}{l}\text { Display } \\
\text { Digunakan untuk menampilkan data ke monitor }\end{array}$ \\
\hline
\end{tabular}




\section{HASIL DAN PEMBAHASAN}

\subsection{Hasil Perancangan Sistem}

a. Flowchart

Alur penentuan kinerja karyawan secara umum di tunjukkan pada gambar 3.1

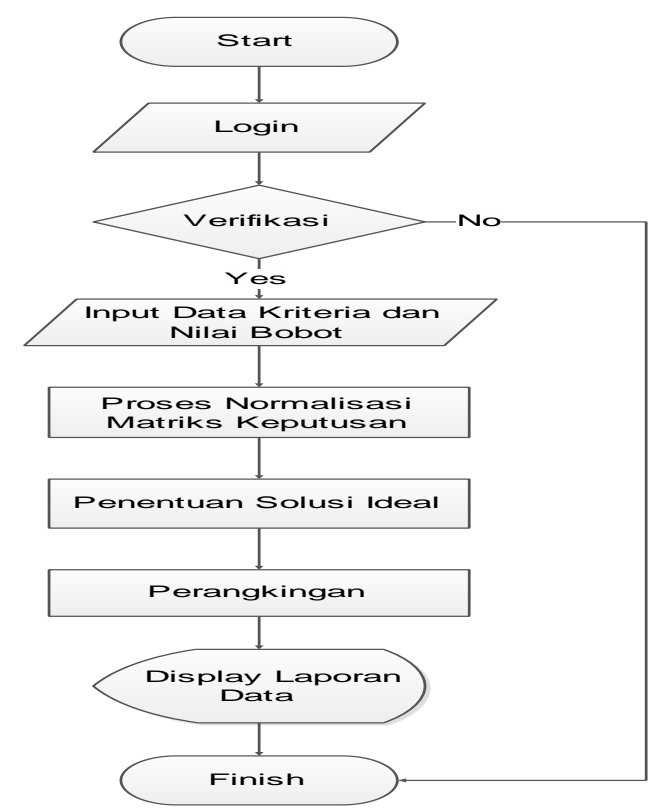

\section{Gambar 3.1 Flowchart Diagram}

\section{b. ERD (Entity Relation Diagram)}

Berikut adalah Relasi etitas-entitas dari sistem penentuan kinerja karyawan Wong Solo ditunjukkan pada gambar 3.2

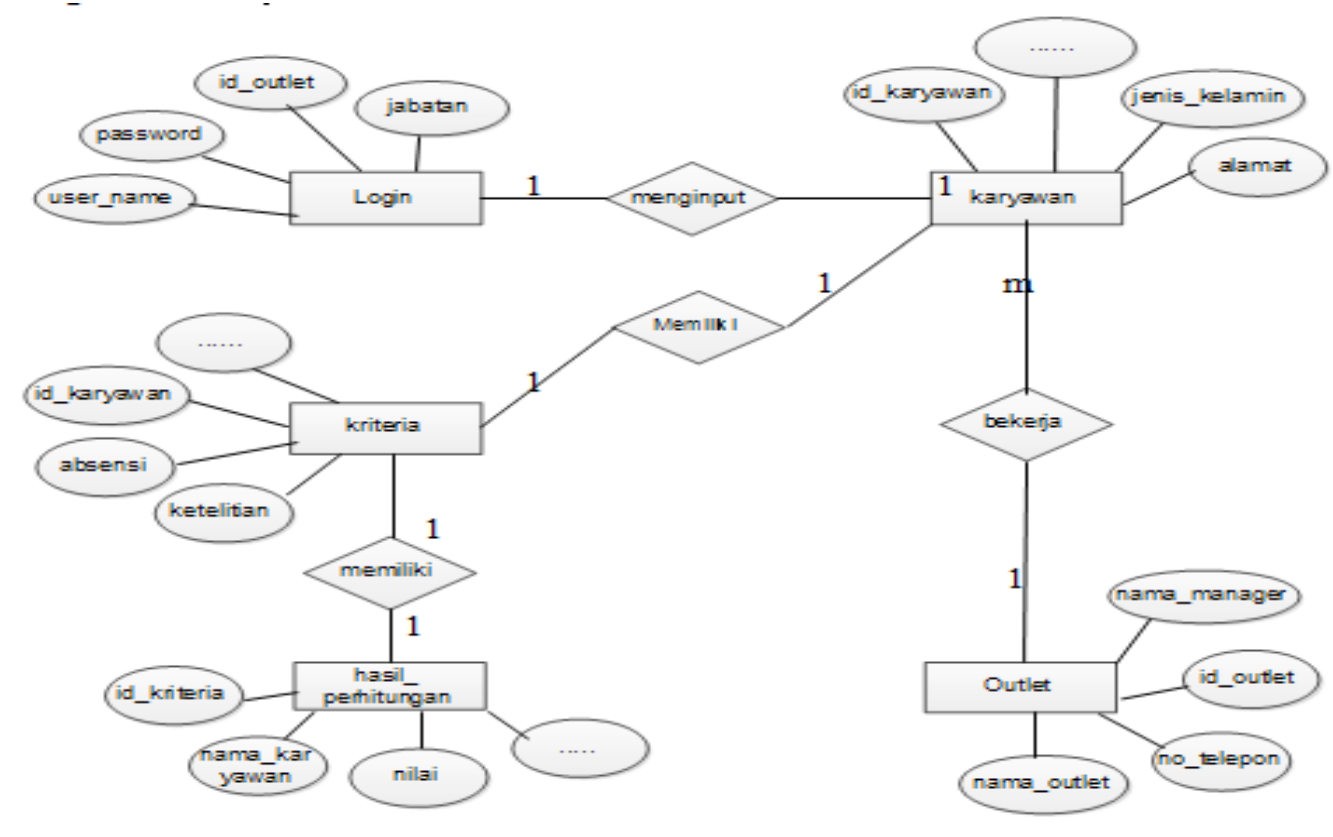

Gambar 3.2 Entity Relation Diagram 


\subsection{Hasil Analisis Pengujian}

\subsubsection{Kinerja Karyawan}

Dalam pengujian ini diambil 25 data sample dari 1 periode pengukuraan kinerja karyawan. Kemudian Data sample digolongkan ke dalam kriteria yang telah ditentukan. Dibentuk rating kecocokan untuk setiap alternatif yang dapat dilihat pada tabel berikut.

Tabel 3.2.1 Rating Kecocokan dari Alternatif

\begin{tabular}{|l|l|l|l|l|l|}
\hline Alternatif & $\mathrm{C} 01$ & $\mathrm{C} 02$ & $\mathrm{C} 03$ & $\mathrm{C} 04$ & $\mathrm{C} 05$ \\
\hline A001 & 4 & 5 & 3 & 4 & 4 \\
\hline A002 & 5 & 3 & 4 & 5 & 5 \\
\hline A003 & 3 & 2 & 5 & 4 & 4 \\
\hline A004 & 4 & 4 & 4 & 5 & 3 \\
\hline A005 & 3 & 5 & 3 & 3 & 5 \\
\hline A006 & 2 & 5 & 5 & 4 & 4 \\
\hline A007 & 4 & 3 & 3 & 5 & 3 \\
\hline A008 & 5 & 4 & 5 & 3 & 5 \\
\hline A009 & 3 & 2 & 4 & 4 & 2 \\
\hline A010 & 4 & 5 & 3 & 5 & 5 \\
\hline & & & & & \\
\hline A011 & 3 & 4 & 4 & 5 & 5 \\
\hline A012 & 4 & 5 & 5 & 4 & 5 \\
\hline A013 & 5 & 5 & 5 & 4 & 5 \\
\hline A014 & 5 & 5 & 5 & 4 & 5 \\
\hline A015 & 4 & 4 & 4 & 3 & 5 \\
\hline A016 & 3 & 3 & 4 & 5 & 4 \\
\hline A017 & 2 & 2 & 3 & 5 & 3 \\
\hline A018 & 3 & 3 & 3 & 4 & 4 \\
\hline A019 & 4 & 4 & 4 & 3 & 4 \\
\hline A020 & 4 & 3 & 5 & 5 & 5 \\
\hline A021 & 4 & 4 & 5 & 5 & 5 \\
\hline A022 & 5 & 4 & 5 & 4 & 4 \\
\hline A023 & 3 & 4 & 4 & 4 & 4 \\
\hline A024 & 3 & 5 & 3 & 4 & 4 \\
\hline A025 & 3 & 5 & 3 & 4 & 3 \\
\hline & & & & & \\
\hline
\end{tabular}


a. Menentukan matriks keputusan yang ternormalisasi.

Untuk melakukan normalisasi kita harus mengkuadratkan setiap elemen matriks pada tabel 3.2,1 misal untuk cell A01-C04 bernilai 4 dikuadratkan menjadi $4 * 4=16$. Kemudian Hasilnya di jumlahkan seperti tabel berikut ini:

Tabel 3.2.2 Normalisasi Tahap 1

\begin{tabular}{|l|l|l|l|l|l|}
\hline Alternatif & C01 & C02 & C03 & C04 & C05 \\
\hline A001 & 4 & 5 & 3 & 4 & 4 \\
\hline A002 & 5 & 3 & 4 & 5 & 5 \\
\hline A003 & 3 & 2 & 5 & 4 & 4 \\
\hline A004 & 4 & 4 & 4 & 5 & 3 \\
\hline A005 & 3 & 5 & 3 & 3 & 5 \\
\hline A006 & 2 & 5 & 5 & 4 & 4 \\
\hline A007 & 4 & 3 & 3 & 5 & 3 \\
\hline A008 & 5 & 4 & 5 & 3 & 5 \\
\hline A009 & 3 & 2 & 4 & 4 & 2 \\
\hline A010 & 4 & 5 & 3 & 5 & 5 \\
\hline A011 & 3 & 4 & 4 & 5 & 5 \\
\hline A012 & 4 & 5 & 5 & 4 & 5 \\
\hline A013 & 5 & 5 & 5 & 4 & 5 \\
\hline A014 & 5 & 5 & 5 & 4 & 5 \\
\hline A015 & 4 & 4 & 4 & 3 & 5 \\
\hline A016 & 3 & 3 & 4 & 5 & 4 \\
\hline A017 & 2 & 2 & 3 & 5 & 3 \\
\hline A018 & 3 & 3 & 3 & 4 & 4 \\
\hline A019 & 4 & 4 & 4 & 3 & 4 \\
\hline A020 & 4 & 3 & 5 & 5 & 5 \\
\hline A021 & 4 & 4 & 5 & 5 & 5 \\
\hline A022 & 5 & 4 & 5 & 4 & 4 \\
\hline A023 & 3 & 4 & 4 & 4 & 4 \\
\hline A024 & 3 & 5 & 3 & 4 & 4 \\
\hline A025 & 3 & 5 & 3 & 4 & 3 \\
\hline Total & 358 & 410 & 425 & 453 & 459 \\
\hline & & & & & \\
\hline
\end{tabular}

Normalisasi tahap 2

Setelah mendapat total, tinggal menormalisasikan dengan cara membagi setiap elemen matriks tabel 3.2.3 dengan akar (sqrt) dari total baris yang bersesuaian, hasilnya seperti berikut: 
Tabel 3.2.3 Normalisasi Tahap 2

\begin{tabular}{|l|l|l|l|l|l|}
\hline \multirow{2}{*}{ Alternatif } & \multicolumn{1}{|c|}{$\mathrm{C} 01$} & \multicolumn{1}{|c|}{$\mathrm{C} 02$} & \multicolumn{1}{|c|}{$\mathrm{C} 03$} & \multicolumn{1}{|c|}{$\mathrm{C} 04$} & \multicolumn{1}{|c|}{$\mathrm{C} 05$} \\
\hline A001 & & & & & \\
\hline A002 & 0,211407 & 0,246932 & 0,145521375 & 0,187936 & 0,186704 \\
\hline A003 & 0,158555 & 0,148159 & 0,1940285 & 0,23492 & 0,23338 \\
\hline A004 & 0,211407 & 0,197546 & 0,1940285 & 0,23492 & 0,140028 \\
\hline A005 & 0,158555 & 0,246932 & 0,145521375 & 0,140952 & 0,23338 \\
\hline A006 & 0,105703 & 0,246932 & 0,242535625 & 0,187936 & 0,186704 \\
\hline A007 & 0,211407 & 0,148159 & 0,145521375 & 0,23492 & 0,140028 \\
\hline A008 & 0,264258 & 0,197546 & 0,242535625 & 0,140952 & 0,23338 \\
\hline A009 & 0,158555 & 0,098773 & 0,1940285 & 0,187936 & 0,093352 \\
\hline A010 & 0,211407 & 0,246932 & 0,145521375 & 0,23492 & 0,23338 \\
\hline A011 & 0,158555 & 0,197546 & 0,1940285 & 0,23492 & 0,23338 \\
\hline A012 & 0,211407 & 0,246932 & 0,242535625 & 0,187936 & 0,23338 \\
\hline A013 & 0,264258 & 0,246932 & 0,242535625 & 0,187936 & 0,23338 \\
\hline A014 & 0,264258 & 0,246932 & 0,242535625 & 0,187936 & 0,23338 \\
\hline A015 & 0,211407 & 0,197546 & 0,1940285 & 0,140952 & 0,23338 \\
\hline A016 & 0,158555 & 0,148159 & 0,1940285 & 0,23492 & 0,186704 \\
\hline A017 & 0,105703 & 0,098773 & 0,145521375 & 0,23492 & 0,140028 \\
\hline A018 & 0,158555 & 0,148159 & 0,145521375 & 0,187936 & 0,186704 \\
\hline A019 & 0,211407 & 0,197546 & 0,1940285 & 0,140952 & 0,186704 \\
\hline A020 & 0,211407 & 0,148159 & 0,242535625 & 0,23492 & 0,23338 \\
\hline A021 & 0,211407 & 0,197546 & 0,242535625 & 0,23492 & 0,23338 \\
\hline A022 & 0,264258 & 0,197546 & 0,242535625 & 0,187936 & 0,186704 \\
\hline A023 & 0,158555 & 0,197546 & 0,1940285 & 0,187936 & 0,186704 \\
\hline A024 & 0,158555 & 0,246932 & 0,145521375 & 0,187936 & 0,186704 \\
\hline A025 & 0,158555 & 0,246932 & 0,145521375 & 0,187936 & 0,140028 \\
\hline
\end{tabular}

Angka-angka tersebut di dapat dari membagi angka alternatif dengan akar dari jumlah kuadrat angkan alternatif, contohnya sebagai berikut :

$\mathrm{A} 01-\mathrm{C} 01=4 / \operatorname{sqrt}(359)=0,211407$

$\mathrm{A} 02-\mathrm{C} 02=5 / \operatorname{sqrt}(410)=0,246932$

b. Menghitung normalisasi terbobot

Cara menghitung angka normalisasi terbobot adalah dengan mengalikan angka pada tabel 3.2.3 dengan angka bobot.

Contoh: $0,211407 * 5=1,321291$

$0,246932 * 4=0,592638$ 
Tabel 3.2.4 Normalisasi Terbobot

\begin{tabular}{|l|l|l|l|l|l|}
\hline \multicolumn{1}{|c|}{ Bobot } & \multicolumn{1}{c|}{$\mathbf{5}$} & \multicolumn{1}{c|}{$\mathbf{4}$} & \multicolumn{1}{c|}{$\mathbf{2}$} & \multicolumn{1}{c|}{$\mathbf{3}$} & \multicolumn{1}{c|}{$\mathbf{2}$} \\
\hline Alternatif & \multicolumn{1}{c}{ C01 } & \multicolumn{1}{c|}{ C02 } & \multicolumn{1}{c|}{ C03 } & \multicolumn{1}{c|}{ C04 } & \multicolumn{1}{c|}{ C05 } \\
\hline A002 & 1,321291 & 0,592638 & 0,388057 & 0,704761 & 0,46676 \\
\hline A003 & 0,792775 & 0,395092 & 0,48507125 & 0,563809 & 0,373408 \\
\hline A004 & 1,057033 & 0,790184 & 0,388057 & 0,704761 & 0,280056 \\
\hline A005 & 0,792775 & 0,98773 & 0,29104275 & 0,422857 & 0,46676 \\
\hline A006 & 0,528516 & 0,98773 & 0,48507125 & 0,563809 & 0,373408 \\
\hline A007 & 1,057033 & 0,592638 & 0,29104275 & 0,704761 & 0,280056 \\
\hline A008 & 1,321291 & 0,790184 & 0,48507125 & 0,422857 & 0,46676 \\
\hline A009 & 0,792775 & 0,395092 & 0,388057 & 0,563809 & 0,186704 \\
\hline A010 & 1,057033 & 0,98773 & 0,29104275 & 0,704761 & 0,46676 \\
\hline A011 & 0,792775 & 0,790184 & 0,388057 & 0,704761 & 0,46676 \\
\hline A012 & 1,057033 & 0,98773 & 0,48507125 & 0,563809 & 0,46676 \\
\hline A013 & 0,264258 & 0,246932 & 0,242535625 & 0,187936 & 0,23338 \\
\hline A014 & 1,321291 & 0,98773 & 0,48507125 & 0,563809 & 0,46676 \\
\hline A015 & 1,057033 & 0,790184 & 0,388057 & 0,422857 & 0,46676 \\
\hline A016 & 0,792775 & 0,592638 & 0,388057 & 0,704761 & 0,373408 \\
\hline A017 & 0,528516 & 0,395092 & 0,29104275 & 0,704761 & 0,280056 \\
\hline A018 & 0,792775 & 0,592638 & 0,29104275 & 0,563809 & 0,373408 \\
\hline A019 & 1,057033 & 0,790184 & 0,388057 & 0,422857 & 0,373408 \\
\hline A020 & 1,057033 & 0,592638 & 0,48507125 & 0,704761 & 0,46676 \\
\hline A021 & 1,057033 & 0,790184 & 0,48507125 & 0,704761 & 0,46676 \\
\hline A022 & 1,321291 & 0,790184 & 0,48507125 & 0,563809 & 0,373408 \\
\hline A023 & 0,792775 & 0,790184 & 0,388057 & 0,563809 & 0,373408 \\
\hline A024 & 0,792775 & 0,98773 & 0,29104275 & 0,563809 & 0,373408 \\
\hline A025 & 0,792775 & 0,98773 & 0,29104275 & 0,563809 & 0,280056 \\
\hline max & 1,321291 & 0,98773 & 0,48507125 & 0,704761 & 0,46676 \\
\hline Min & 0,264258 & 0,246932 & 0,242535625 & 0,187936 & 0,186704 \\
\hline & & & & & \\
\hline
\end{tabular}

Dari hasil tersebut di ambilah angka maksimal dan angka minimal dari setiap kolom, sebagai acuan nilai idela positif dan negatif

c. Menentukan matriks solusi ideal positif dan matriks solusi ideal negatif.

Matriks solusi ideal didapat berdasarkan normalisasi terbobot dan atribut kriteria (cost atau benefit). Solusi ideal positif diambil nilai maksimal dari normalisasi terbobot jika atribut kriteria benefit, jika cost diambil nilai minimalnya. Sebaliknya solusi ideal positif diambil nilai minimal dari normalisasi terbobot jika atribut kriteria benefit, jika cost diambil maksimalnya. 


$$
\begin{aligned}
& \text { Positif }=>(\operatorname{mak} \mid \text { benefit }),(\min \mid \text { cost }) \\
& \text { Negatif }=>(\min \mid \text { benefit }),(\operatorname{mak} \mid \text { cost })
\end{aligned}
$$

Hasilnya bisa dilihat pada tabel berikut:

Tabel 3.2.5 Nilai Positif dan Negatif

\begin{tabular}{|l|l|l|l|l|l|}
\hline & Benefit & Benefit & Benefit & Benefit & Cost \\
\hline Positif & 1,321291 & 0,98773 & 0,48507125 & 0,704761 & 0,186704 \\
\hline Negatif & 0,264258 & 0,246932 & 0,242535625 & 0,187936 & 0,46676 \\
\hline
\end{tabular}

Solusi ideal positif diambil nilai maksimal dari normalisasi terbobot jika atribut kriteria benefit, jika cost diambil nilai minimalnya. Sebaliknya solusi ideal positif diambil nilai minimal dari normalisasi terbobot jika atribut kriteria benefit, jika cost diambil maksimalnya.

d. Menentukan nilai preferensi (ci) untuk setiap alternatif. Nilai preferensi merupakan kedekatan suatu alternatif terhadap solusi ideal.

$$
C_{i}=\frac{d_{i^{-}}}{d_{i^{*}}+d_{i^{+}}}
$$

$$
\text { Contoh : } \quad 0,741138149=\frac{1,153091}{1,153091+0,402747}
$$

keterangan:

nilai $\mathrm{c}_{\mathrm{i}}$ yang lebih besar menunjukkan prioritas alternatif.

Tabel 3.2.6 Nilai Preverensi

\begin{tabular}{|l|l|l|l|}
\hline Alternatif & POSITIVE & NEGATIVE & PREFERENSI \\
\hline A001 & 0,402747 & 1,153091 & 0,741138149 \\
\hline A002 & 0,493904 & 1,234956 & 0,714318229 \\
\hline A003 & 0,827813 & 0,714212 & 0,463164996 \\
\hline A004 & 0,356347 & 1,116583 & 0,758069239 \\
\hline A005 & 0,689114 & 0,94109 & 0,577283584 \\
\hline A006 & 0,82657 & 0,909633 & 0,523920828 \\
\hline A007 & 0,521816 & 1,025828 & 0,662832176 \\
\hline A008 & 0,443763 & 1,235496 & 0,735738696 \\
\hline A009 & 0,812298 & 0,736321 & 0,475469454 \\
\hline A010 & 0,431174 & 1,202802 & 0,736119882 \\
\hline A011 & 0,637336 & 0,928836 & 0,593061294 \\
\hline A012 & 0,410038 & 1,173617 & 0,741081079 \\
\hline A013 & 1,412165 & 0,23338 & 0,141825382 \\
\hline A014 & 0,313527 & 1,36609 & 0,813334467 \\
\hline A015 & 0,525519 & 0,999989 & 0,655512132 \\
\hline A016 & 0,692602 & 0,834171 & 0,546362179 \\
\hline A017 & 1,012953 & 0,629367 & 0,383218455 \\
\hline A018 & 0,726499 & 0,742422 & 0,505419948 \\
\hline A019 & 0,482283 & 1,004337 & 0,675584035 \\
\hline A020 & 0,55169 & 1,036309 & 0,652588049 \\
\hline
\end{tabular}




\begin{tabular}{|l|l|l|l|}
\hline Alternatif & POSITIVE & NEGATIVE & PREFERENSI \\
\hline A021 & 0,432768 & 1,117831 & 0,720902613 \\
\hline A022 & 0,306187 & 1,273287 & 0,806146305 \\
\hline A023 & 0,618459 & 0,863495 & 0,582673125 \\
\hline A024 & 0,609674 & 0,990181 & 0,618919094 \\
\hline A025 & 0,587843 & 1,003295 & 0,630552146 \\
\hline
\end{tabular}

e. Hasil perhitungan dan perangkingan

Berikut ini adalah hasil penghitungan dan perangkingan nilai alternatif terbobot mulai dari nilai terbesar ke nilai terkecil.

Tabel 3.2.7 Tabel Hasil Perhitungan dan Perangkingan

\begin{tabular}{|l|l|l|l|}
\hline ID Karyawan & Nama Karyawan & Nilai & Id \\
\hline K014 & Umiyati & 0,813334467 & KR014 \\
\hline K022 & Nur Hayati & 0,806146305 & KR022 \\
\hline K004 & Dea Almariyah Ana & 0,758069239 & KR004 \\
\hline K001 & Andi Susilo & 0,741138149 & KR001 \\
\hline K012 & Ahzzam Erendy & 0,741081079 & KR012 \\
\hline K010 & Roni Kurniawan & 0,736119882 & KR010 \\
\hline K008 & Santoso & 0,735738696 & KR008 \\
\hline K021 & R. Aditya Noviantoro & 0,720902613 & KR021 \\
\hline K002 & Ariyanto Mulya & 0,714318229 & KR002 \\
\hline K019 & Wiwin Auliya & 0,675584035 & KR019 \\
\hline K007 & Amalia Kamila Yuli & 0,662832176 & KR007 \\
\hline K015 & Lauhul Mahfud & 0,655512132 & KR015 \\
\hline K020 & Zamsuri & 0,652588049 & KR020 \\
\hline K025 & Suci Rahayu & 0,630552146 & KR025 \\
\hline K024 & Ari Bagus Satrio & 0,618919094 & KR024 \\
\hline K011 & Firdawati Rukmana & 0,593061294 & KR011 \\
\hline K023 & Qorori Aina Salsabilla & 0,582673125 & KR023 \\
\hline K005 & Danang Kiratama & 0,577283584 & KR005 \\
\hline K016 & Muayat & 0,546362179 & KR016 \\
\hline K006 & Bella Ananda & 0,523920828 & KR006 \\
\hline K018 & Mohammad Hanafi & 0,505419948 & KR018 \\
\hline K009 & Anita Salsabila & 0,475469454 & KR009 \\
\hline K003 & Helmi Agusto Sah & 0,463164996 & KR003 \\
\hline K017 & Saafila Fajariyah & 0,383218455 & KR017 \\
\hline K013 & Moh Afandy & 0,141825382 & KR013 \\
\hline & & & \\
\hline & & 0 & 0 \\
\hline
\end{tabular}

Dapat di simpulkan bahwa karyawan terbaik adalah umiyati dengan nilai preferensi 0,813334467 dan karyawan terburuk adalah Moh Afandy dengan nilai preferensi 0,141825382 . 


\subsection{Implementasi}

a. Tampilan Menu Utama

Pada form menu utama terdapat semua menu yang ada dalam sistem antara lain: input data karyawan, input kriteria penilaian, input data outlet dan laporan. Dalam menu utama memiliki menu - menu yang berbeda berdasarkan jabatan yang dipilih dalam login yang dilakukan oleh pengguna. Form menu utama dapat dilihat pada gambar 3.4

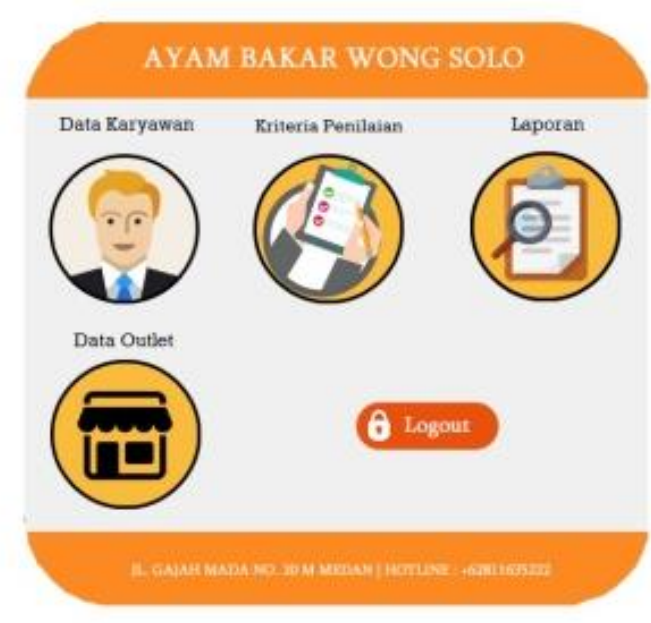

Gambar 3.3 Form menu utama

b. Tampilan Input Data Karyawan

Form input data karyawan ini dapat di akses oleh HRD. Dalam form ini HRD akan menginputkan data karyawan secara lengkap agar dapat digunakan untuk alernatif dalam perbandingan kinerja karyawan.

c. Tampilan Form Outlet

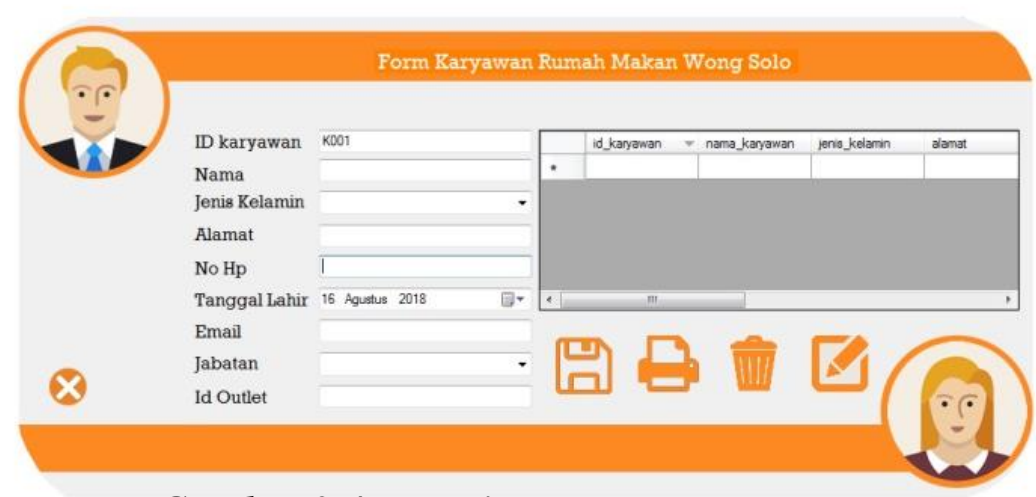

Gambar 3.4 Form input Data Karyawan

From input data outlet ini dapat di akses oleh HRD. Dalam form ini akan di inputkan data Outlet Rumah Makan Wong Solo, yang kemudian untuk menentukan id outlet. 


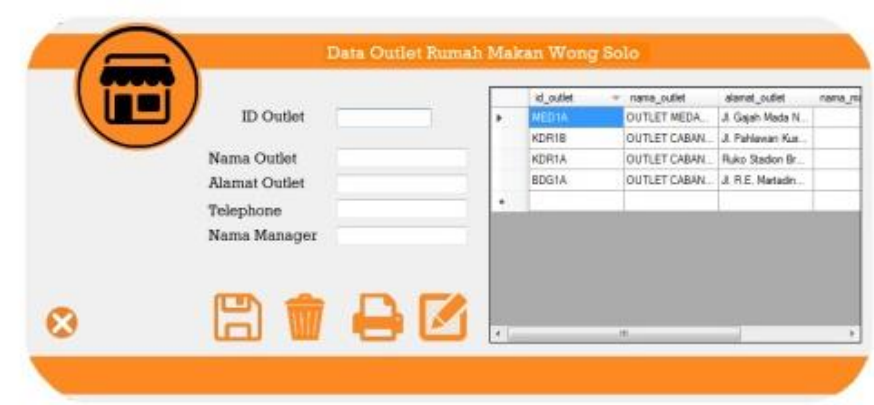

\section{Gambar 3.5 Form input data Outlet}

d. Tampilan Input data Kriteria dan penghitungan SPK

Setiap karyawan memiliki nilai - nilai kriteria yang akan diinputkan ke dalam sistem yang menjadi bahan perhitungan dan kemudian dibobot dalam sistem. Untuk menentukan karyawan mana yang terbaik dan terburuk.

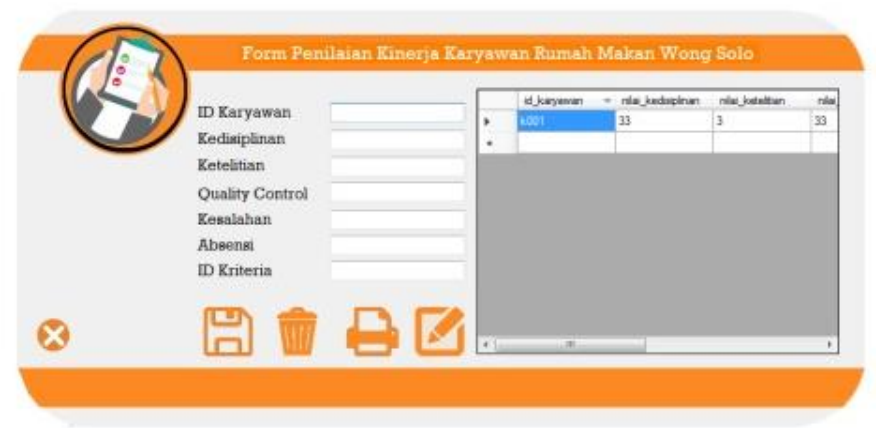

\section{Gambar 3.6 Form Input Data Kriteria}

e. Tampilan Form Laporan

Form laporan berisi : laporan outlet, laporan karyawan, laporan karyawan terbaik. Masing-masing laporan akan ditampilkan dengan bantuan tombol yang ada.

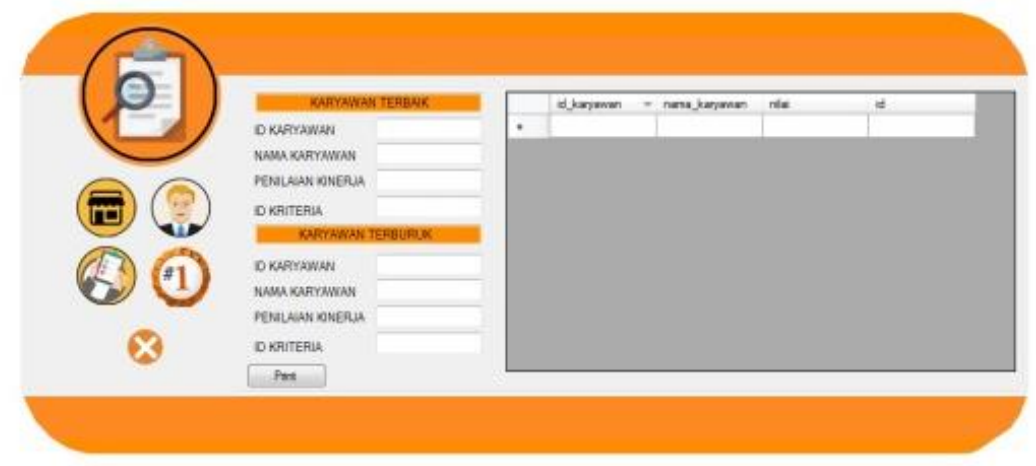

Gambar 3.7 Form Laporan 


\section{KESIMPULAN DAN SARAN}

\subsection{Kesimpulan}

Berdasarkan penelitian dan pembahasan yang dilakukan, maka dapat disimpulkan beberapa hal sebagai berikut:

1. Metode Technique For Other Reference by Similarity Ideal Solution dapat diterapkan ke dalam sistem pendukung keputusan pengukur kinerja karyawan yang digunakan sebagai rekomendasi HRD rumah makan Wong Solo Kediri untuk menentukan karyawan terbaik dan terburuk.

2. Perhitungan menggunakan Metode Technique For Other Reference by Similarity Ideal Solution ini sesuai dengan perhitugan manual.

3. Dengan adanya sistem ini, pihak Rumah Makan Wong Solo khususnya HRD dapat mengukur kinerja karyawan dengan lebih efisien dan cepat dari pada dengan cara manual.

\subsection{Saran}

Berdasarkan pengujian yang telah dilakukan pada sistem ini tentunya masih banyak kekurangan dan kelemahan yang ada dalam sistem. Berikut beberapa saran dari penulis:

1. Agar sistem ini dikembangkan menjadi sistem online, sebab Rumah Makan Wong Solo memiliki banyak Outlet yang tersebar diseluruh Indonesia.

2. Sementara sistem ini masih menangani pengukur kinerja karyawan, diharapkan sistem ini bisa dikembangkan lagi menjadi sistem yang lebih kopleks yang menangani lebih banyak bagian seperti absesi, penggajian dengan Metode Technique For Other Reference by Similarity Ideal Solution ataupun dengan metode lain. 


\section{DAFTAR PUSTAKA}

[1]. Jogiyanto, 1989. Analisis dan Desain Sistem. Yogyakarta: Andi.

[2]. Kusumadewi, S., Hartati, S., Harjoko, A., \& Wardoyo, R. , 2006. Fuzzy MultipleAttribute Decision Making. Yogyakarta : Graha Ilmu.

[3] Sutanta, E., 1996. Sistem Basis Data : Konsep Penerapan dalam Sistem Informasi Manajemen. Yogyakarta: Andi Offset.

[4] Sprague et.al, 1993. Decision Support Systems: Putting Theory into Practice, Prentice Hall College Div; 3 Sub edition (February 1993): New Jersey, United States Upper Saddle River.

[5] Turban, Efraim, 1995. Decision Support and Expert Systems: Management Support Systems. New Jersey: Prentice-Hall International.

[6] Behzadiana, M., Otaghsara, S.K., Yazdani, M., Ignatius, J., 2012. A state-of the-art survey of TOPSIS applications, Expert Systems with Applications 39 (2012) 13051-13069.

[7] Kusumadewi, S., Hartati, S., Harjoko, A., Wardoyo, R., 2006. Fuzzy Multi Attribute Decision Making (Fuzzy MADM). Yogyakarta: Graha Ilmu.

[8] Hwang, Ching-Lai, \& Kwangsun Yoon, 1981, Multiple Attribute Decision Making, Methods and Application. New York: Spinger-Verlag.

[9] Moh. Ramdhan., Ferry Jie, 2015, Penerapan ANP-TOPSIS untuk Pengukuran Kinerja Human Resources Procurement Section, http://ejournal.undip.ac.id/index.php/jsinbis.

[10] Helmi kurniawan, 2015. Sistem Pendukung Keputusan Penilaian Kinerja Karyawan Menggunakan Metode TOPSIS Berbasis Web Pada CV.Surya Network Indonesia. https://www.neliti.com/id/publications/170558/sistempendukung-keputusan-penilaian-kinerja-karyawan-menggunakan-metodetopsis. https://www.neliti.com/id/publications/170558/sistem-pendukungkeputusan-penilaian-kinerja-karyawan-menggunakan-metode-topsis. 